\title{
Carbohydrate and Protein Immobilization onto Solid Surfaces by Sequential Diels-Alder and Azide-Alkyne Cycloadditions
}

Xue-Long Sun, ${ }^{1 *}$ Cheryl L. Stabler, ${ }^{1}$ Chrystelle S. Cazalis, ${ }^{1}$ and Elliot L. Chaikof ${ }^{1,2^{*}}$

${ }^{I}$ Departments of Surgery and Biomedical Engineering, Emory University, Atlanta, GA

30322, ${ }^{2}$ School of Chemical and Biomolecular Engineering, Georgia Institute of

Technology, Atlanta, GA 30332

Supporting Information

Synthesis of bifunctional PEG linkers

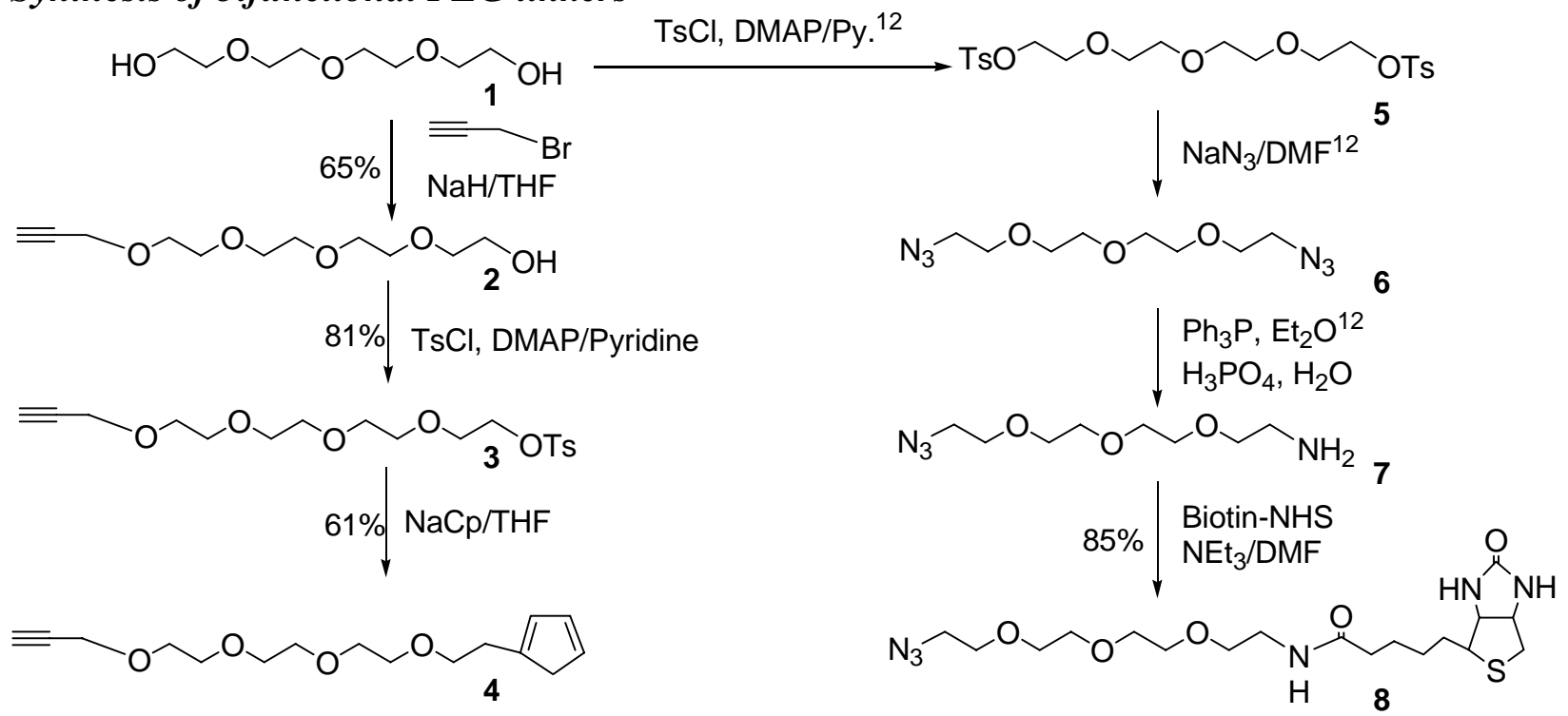


O-Propargyl-tetra(ethylene glycol) (2).
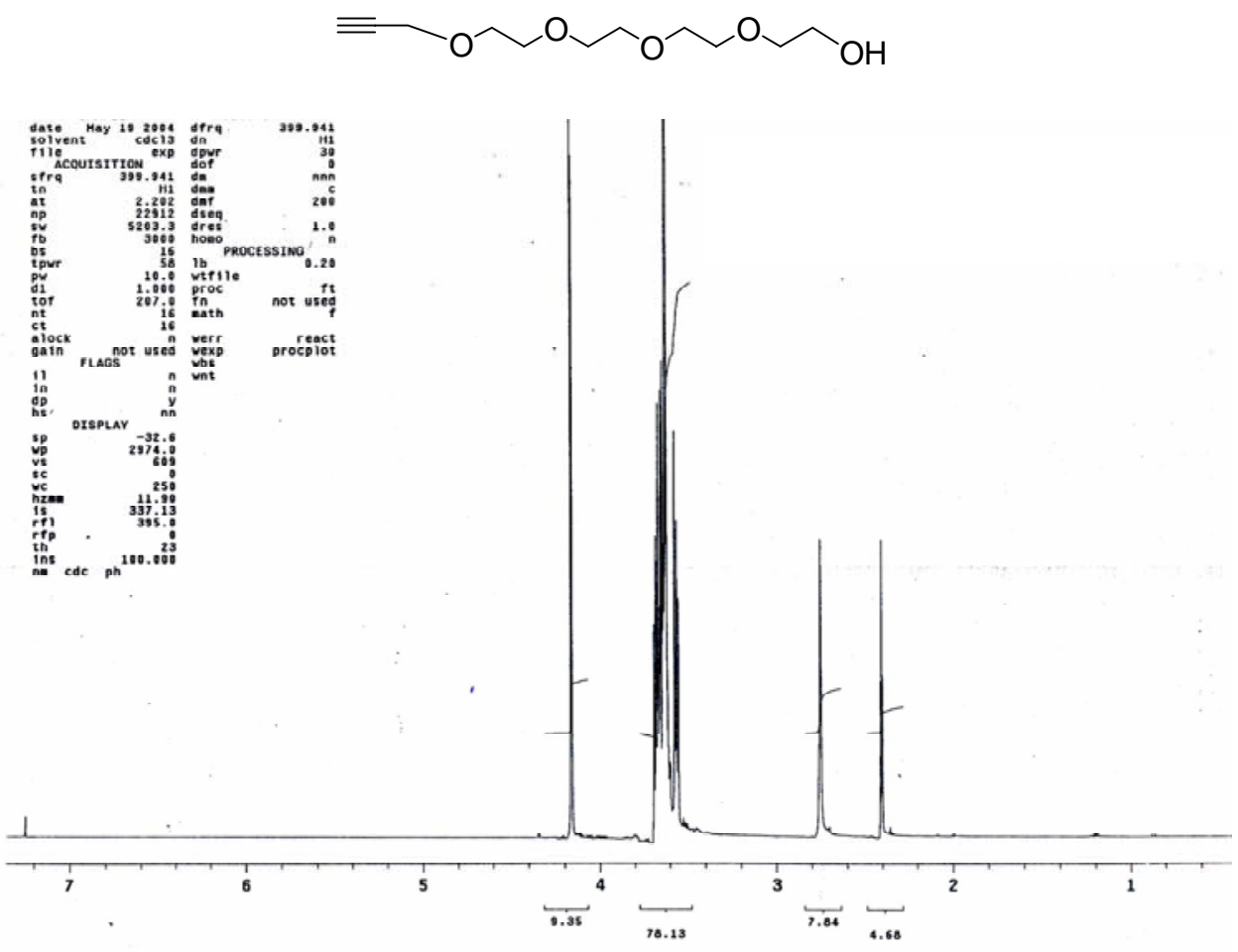

O-Propargyl-tetra(ethylene glycol) tosylate (3).
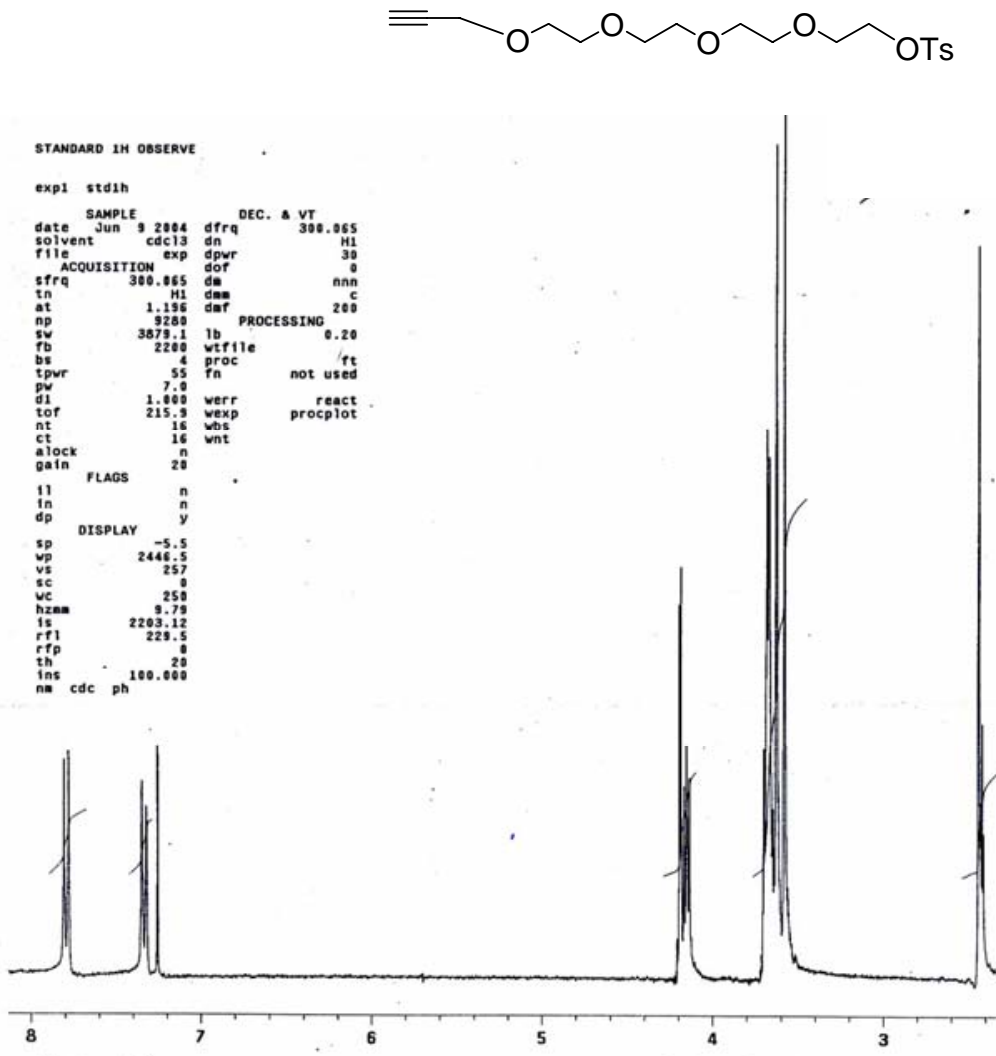
2-O-Propargyl-8-O-cyclopentadieneethyl tri(ethylene glycol) (4).
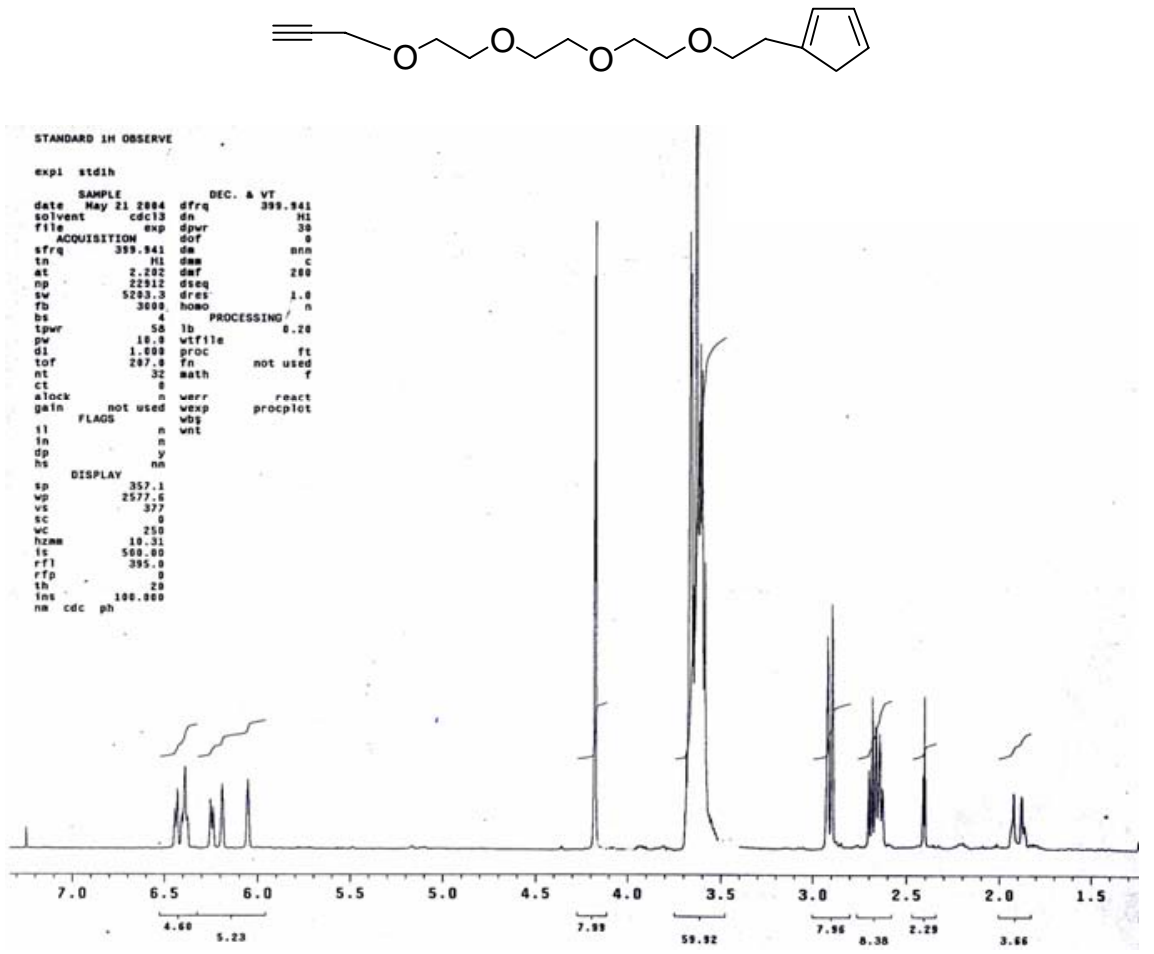

Azidoethyl-di(ethylene glycol) ethylamino biotin (8).
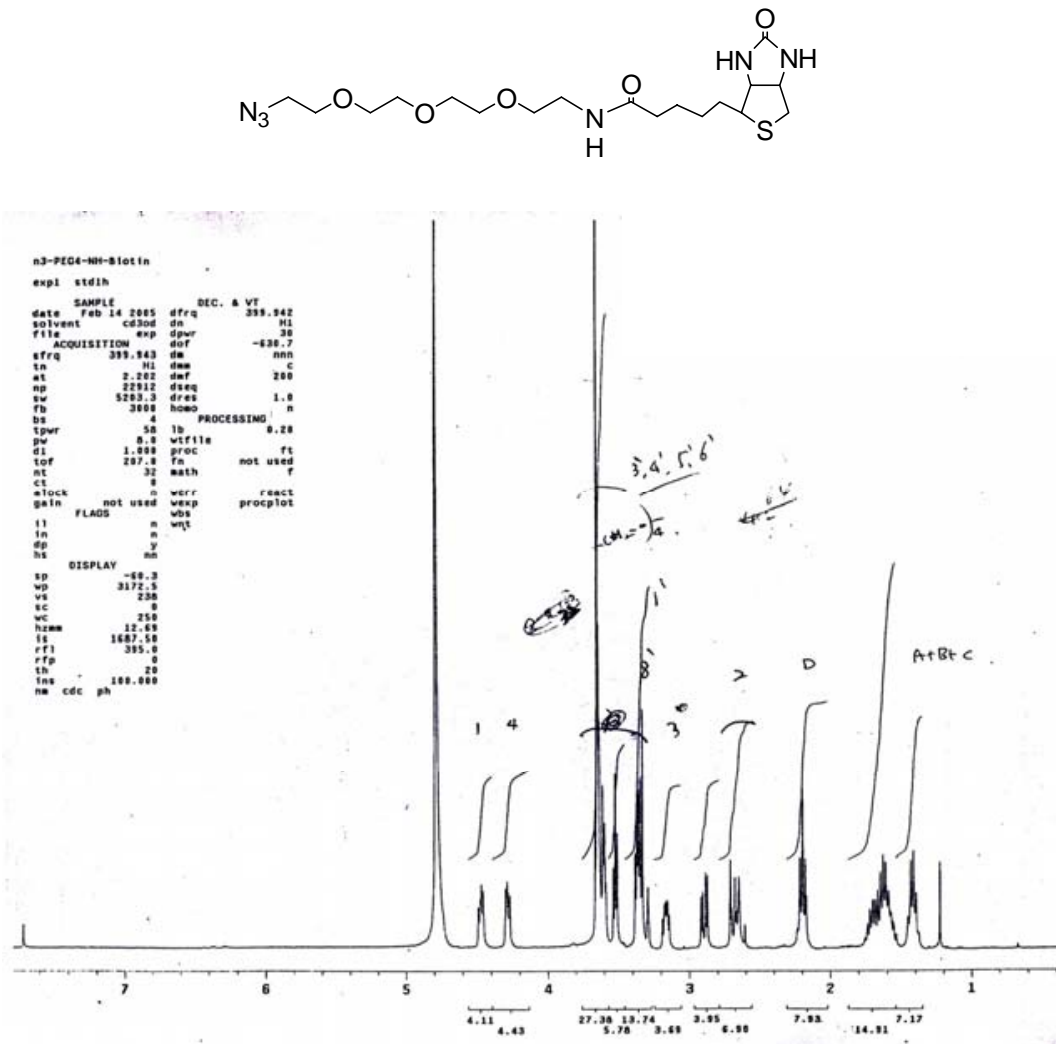